\title{
Natalia Sowińska*
}

\section{REKOMENDACJA KSIĄŻKI ZAKLAMANE JEDZENIE AUTORSTWA DR HANNY STOLIŃSKIEJ}

DOI: $10.15611 /$ nit.2019.3.05

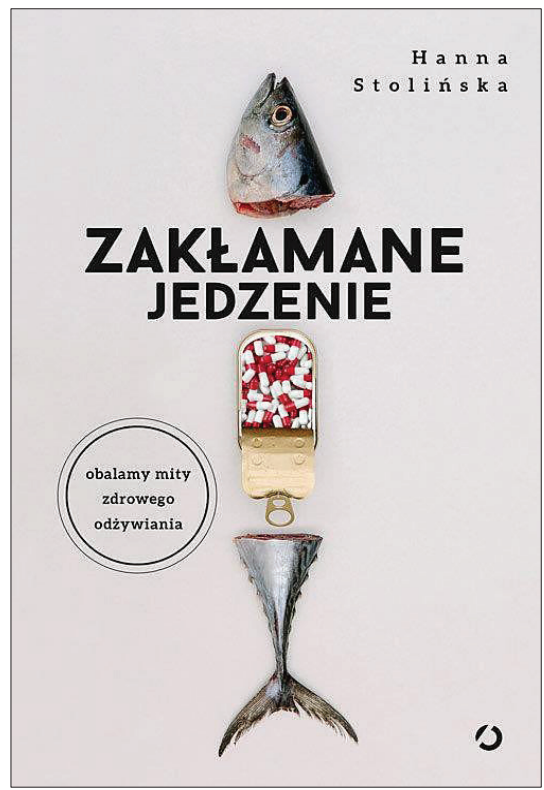

Rekomenduję z całym przekonaniem książkę pt. Zaktamane jedzenie napisaną przez dr Hannę Stolińską, wydaną przez Wydawnictwo Otwarte w 2020 roku. Głównym celem tej publikacji jest przybliżenie zasad zdrowego żywienia, metodologii badań naukowych i teorii narastających przez wiele lat na temat żywienia.

Książka ma charakter popularnonaukowy - jej zadaniem jest przybliżenie osobom niezwiązanym $\mathrm{z}$ nauką o żywieniu, skąd wzięły się mity na temat żywności i żywienia oraz ich wpływu na zdrowie człowieka. Jej atutem niewątpliwie jest przedstawienie aktualnego stanu wiedzy z zakresu żywienia, opartego na najnowszej literaturze naukowej i opiniach przedstawicieli rozmaitych jednostek naukowych.

Treść książki została podzielona na sześć głównych rozdziałów, w których zostały omówione:

1) zalecenia dotyczące zdrowego żywienia,

2) rozróżnienie badań naukowych i ocena przekazywanych informacji,

3) determinanty zdrowia,

4) fałszywe teorie żywieniowe,

5) superfoods,

6) jak pogodzić zalecenia żywieniowe w codziennym życiu.

Każdy z rozdziałów rozpoczyna krótki wstęp mający na celu przybliżenie czytelnikowi tematyki omawianej w dalszej części.

* Mgr Natalia Sowińska jest dietetyczką i psychodietetyczką. 
W rozdziale pierwszym publikacji przedstawiono zalecenia dotyczące zdrowego żywienia z dokładnym opisaniem grup produktów spożywczych. Rozdział ten ma na celu przybliżenie czytelnikowi aktualnych zasad zdrowego żywienia i wartości odżywczej spożywanych produktów oraz stworzenie solidnych podstaw wiedzy potrzebnych do zrozumienia kolejnych rozdziałów. Zostały wymienione składniki odżywcze warzyw i owoców, łącznie z ciekawostkami na temat prozdrowotnych właściwości związków wpływających na ich kolor, omówione zostały produkty zbożowe, a opis ten uzupełniono cennymi wskazówkami dotyczącymi ich wyboru w zależności od stanu zdrowia. Następnie dokładnie opisano grupę produktów mlecznych, ich wpływ na zdrowie i zalecaną ilość dziennego ich spożycia. Kolejną opisaną grupą były produkty będące głównym źródłem białka w diecie: mięso, drób, wędliny, ryby, jaja i nasiona roślin strączkowych. W książce autorka wskazała, że są one nieodłączną częścią zdrowo zbilansowanej diety, a odpowiedni ich dobór może mieć prozdrowotne właściwości. Kolejna szeroko opisana grupa produktów spożywczych to thuszcze zwierzęce i roślinne - omówiono m.in. ich wpływ na zdrowie człowieka. Czytelnik z tego podrozdziału dowie się o ukrytych źródłach tłuszczu i czemu zostały one umieszczone na samym szczycie piramidy zdrowego żywienia. Ostatnią opisaną ciekawą grupą produktów były słodycze i ukryte źródła sacharozy w diecie. Wyjaśniona została obecność cukru w piramidzie zdrowego żywienia i skutki wysokiej podaży tego składnika. W tym samym rozdziale autorka przedstawiła rys historyczny zaleceń żywieniowych, zaczynając od Basic seven obowiązujących w USA w latach 1916-1940 i Basic four (1959-1992). W dalszej części mogliśmy się dowiedzieć się o pierwszej piramidzie zdrowego żywienia obowiązującej od 1992 r. i jej kolejnych wersjach, w tym polskiej z 2009 r. Wspomniano również o talerzach zdrowego żywienia oraz piramidzie zdrowego żywienia i aktywności fizycznej obowiązującej w Polsce do ubiegłego roku. Rozdział ten pozwoli czytelnikowi prześledzić cały proces tworzenia zaleceń i ich zmian w zależności od aktualnych potrzeb społeczeństwa.

W części drugiej autorka skupiła się na dokładnym i jednocześnie prostym przedstawieniu metodologii badań naukowych. Czytelnik dowie się m.in. o rodzajach badań naukowych w medycynie i żywieniu, wartości naukowej badań i źródłach klinicznie istotnej, wiarygodnej i aktualnej wiedzy. W obecnych czasach wiele nowości w świecie nauki jest negowanych, dlatego ten rozdział książki jest niezwykle ważny. Czytelnik (osoba niezwiązana z badaniami naukowymi) posiądzie podstawową wiedzę na temat rodzaju badań i ich wykorzystania w opracowywaniu zaleceń żywieniowych.

W części trzeciej autorka skupiła się na odpowiedzi na pytanie: jak dopasować do siebie ogólne zalecenia, skoro każdy organizm jest inny. W tej części opisano determinanty zdrowia według Lalonde’a i praktyczne wskazówki potrzebne do ułożenia zdrowo zbilansowanej diety oraz sposób ich modyfikacji w zależności od stanu zdrowia i stosowanych diet. Po przeczytaniu tego rozdziału czytelnik będzie miał 
odpowiednią wiedzę, żeby na własną rękę wprowadzić odpowiednie zmiany w swojej diecie, bez obawy, że przyniesie to negatywne skutki zdrowotne.

Część czwarta została poświęcona głównemu tematowi książki - omówiono w niej fakty i mity na temat żywienia oraz szeroko rozpowszechnione informacje dotyczące jedzenia. Autorka odpowiedziała na m.in. na pytania, ile jeść posiłków w ciągu dnia, czy okresowe głodówki są zdrowe, jakie diety są modne i czy one działaja. Wymieniła prawdziwe i nieprawdziwe informacje na temat wielu produktów spożywczych, takich jak olej kokosowy, słodziki, soja, margaryna, miód, i wiele więcej. Dokładnie omówiła funkcję i wpływ na zdrowie dodatków do żywności, amigdalinów i okrytego złą sławą glutaminianu sodu. W tym rozdziale autorka przedstawiła ponadto mity żywieniowe. Czytelnik po lekturze poprzednich rozdziałów dzieła bez problemu zrozumie, skąd i dlaczego wzięły się mity, dlaczego nie są prawdziwe i czemu przez wielu są chętnie powielane.

W części piątej zostały przedstawione produkty superfoods, czyli naturalne składniki o wysokiej gęstości odżywczej. Autorka wspomniała, jakie produkty najlepiej wybierać i jak stosować je w diecie. Pokrótce opisała najciekawsze z nich, takie jak maca, nasiona chia, moringa czy chlorella. Nie zabrakło miejsca dla rodzimych produktów superfoods oraz odpowiedzi na pytania dotyczące występowania alergii na superfoods, skutków ubocznych czy stosowania ich u osób z problemami ze strony układu pokarmowego lub stosujących restrykcyjną dietę. Rozdział ten nieco przewrotny, ponieważ superfood są dalekie od jakichkolwiek zakłamań i mitów - uświadamia czytelnikowi, że nawet najprostsze produkty mogą zwiększyć wartość odżywczą zwyczajowo spożywanych posiłków, chroniąc tym samym przed niedoborami składników odżywczych.

Celem części szóstej byla pomoc czytelnikowi w pogodzeniu obszernych zaleceń żywieniowych z codziennym życiem. Autorka stworzyła swojego rodzaju Q\&A (questions \& answers) odnośnie do najczęściej występujących problemów pacjentów i z kilkoma poradami ułatwiającymi wprowadzenie zmian w stylu życia.

Rekomendowana książka bardzo dobrze przedstawia obecne zalecenia żywieniowe i ich praktyczne wykorzystanie. Uzupełniona jest bardzo cennym rozdziałem obejmującym temat badań naukowych, który osobom niezwiązanym z nauką o zdrowiu może wytłumaczyć, czemu wiedza w tej dziedzinie ulega ciagłym zmianom. Publikacja tworzy solidne podstawy do zrozumienia głównego tematu książki, czyli mitów na temat żywności i diet. Zawarte w niej informacje dotyczące fałszywych teorii żywieniowych, które ciaggle są obecne w mediach i prasie, zostały przedstawione w sposób przystępny dla czytelnika i bardzo dokładny. Uważam, że wnikliwe omówienie nie powinno zostawiać cienia wątpliwości, co na ten temat mówi nauka.

Podsumowując, należy stwierdzić, że recenzowne dzieło jest wiedzą w pigułce na temat obecnych zaleceń żywieniowych i sposobu ich stosowania w praktyce oraz tego, jak nie dać się zwieść powszechnie panującym mitom na temat żywności. 